\title{
Effect of environmental factors on the compounds of the essential oil of Lippia citriodora
}

Fariba Amini, ${ }^{1}$,

Gholam Reza Asghari²,

Seyed Mehdi Talebi ${ }^{* 1}$,

Mehry Askary ${ }^{1}$,

Marziyeh Shahbazi ${ }^{1}$

${ }^{1}$ Department of Biology,

Faculty of Science,

Arak University. Arak,

P.O. Box: 38156-8-8349

2 Department of Pharmacognosy,

Faculty of Pharmacy, Isfahan

University of Medical Sciences, Iran
Lippia citriodora is a member of the genus Lippia. The species is endemic to South America, while it is cultivated in the world for the lemon-like aroma emitted by its leaves. In the present study the effects of different $\mathrm{NaCl}$ as well as 24-epibrassinolide concentrations in the essential oil composition were investigated. In total, eleven treatments were studied. The major essential oil components in control plants were: Geranial (22.52\%), Citral (15.88\%) Germacrene D (7.42\%), Caryophyllene (7.11\%), Benzenamine (6.30\%), Spathulenol (6.00\%) and Curcumene (5.44\%). Significant positive/negative correlations occurred between some components with salt concentration. Paired sample tests showed significant differences between major components of an essential oil with salt as well as with 24-epibrassinolide concentrations.

Keywords: epibrassinolide, essential oil, Lippia citriodora, stress, salt

\section{INTRODUCTION}

The genus Lippia of family Verbenaceae has approximately 200 species in the forms of herbs, shrubs and small trees. Different studies showed that this genus has a rich genetic diversity, and for this reason it can synthesize different types of components in its essential oil in different ecological conditions (Catalan, De Lampasona, 2002; Santos-Gomes et al., 2005). Lippia citriodora (Ortega ex Pers.) Humb., Bonpl. et Kunth (Lemon verbena) is a member of this genus, and has different synonyms such as Lippia triphylla (L'Her.) Kuntze and Aloysia triphylla (L'Her.)

\footnotetext{
^Corresponding author. Email: seyedmehdi_talebi@yahoo.com.
}

Britton. This plant is a species endemic to South America and has been introduced into other parts of the world. The Lemon verbena is cultivated mainly for the lemon-like aroma it emits. Leaves of this species are utilized for the preparation of herbal teas and have different medical properties such as antispasmodic, antipyretic, sedative, and digestive. L. citriodora is used in folk medicine in treating different disorders such as asthma, spasms, anxiety, cold, fever, flatulence, colic, diarrhea, indigestion, and insomnia (Valentão et al., 1999; Pascual et al., 2001; Santos-Gomes et al., 2005). Studies have proven that the essential oil from the leaves of this plant has an antimicrobial effect (Duarte et al., 2005). The essential oil from the leaves of the Lemon verbena contains various components the major of them being geranial, 
neral, and limonene (Terblanche, Kornelius, 1996; Sartoratto et al., 2004; Argyropoulou et al., 2007).

Grattan and Grieve (1992) suggested that an increment of salinity in arable land is a major difficulty to crop manufacture in the irrigated fields in arid and semi-arid regions. In the mentioned regions little rainfall, high temperature and evapotranspiration associated with shortage of water and land handling contribute to the salinity knot and pose a threat to agronomy yield (Eraslan et al., 2008).

Brassinosteroids are a type of phyto-components, which can act as hormones in plants (Bishop et al., 2006). Sasse (2003) believed that the mentioned components played key roles in different physiologic processes such as elongation of stem, growth of the pollen tube, vascular differentiation, epinasty of leaves, induction of ethylene biosynthesis, activators of proton pump, regulation of gene expression and the photosynthesis process.

Previous studies showed that Brassinosteroids protect plants from different abiotic stresses such as drought (Behnamnia et al., 2009), temperature (Ogweno et al., 2008), heavy metals (Ali et al., 2008), and salt (Hayat et al., 2010) or biotic stresses such as infection by pathogens (Nakashita et al., 2003).

Because of high importance of L. citriodora essential oil, in the present study the effects of different concentrations of salt $(\mathrm{NaCl})$ and 24-epibrassinolide on the essential oil compositions were investigated and its main components in treated samples and the control plant were compared. As far as we were able to search, the effects of these factors (as a combination) on the composition of the essential oil of the species have not been investigated.

\section{MATERIALS AND METHODS}

\section{Plant material}

Samples of $L$. citriodora were identified on the basis of descriptions provided in valuable references. Plantlets were grown in pots $(10 \times 10 \times 10 \mathrm{~cm})$ containing sand, clay and peat (in proportion of $1: 1: 1$ ). The samples were grown in a growth chamber at the cycle of 16 and $8 \mathrm{~h}$ light and dark, respectively. The temperature was $24 \pm 2{ }^{\circ} \mathrm{C}$ during the day and $16 \pm 2{ }^{\circ} \mathrm{C}$ at night. In total, eleven treatments were used which were classified into three main groups (Table 1). 24-epibrassinolide at 0 , $1,2 \mu \mathrm{m}$ concentration containing $0.1 \%$ Tween

Table 1. Concentration of Epibrassinolide $(\mu \mathrm{m})$ and $\mathrm{NaCl}(\mathrm{mM})$ used for treatments

\begin{tabular}{c|c|c|c}
\hline Treatment & Group & $\begin{array}{c}\text { Salt, } \\
\text { Mm }\end{array}$ & Epibrassinolide \\
\hline control & control & 0 & 0 \\
\hline 1 & $\mathrm{~A}$ & 50 & 0 \\
\hline 2 & $\mathrm{~A}$ & 100 & 0 \\
\hline 3 & $\mathrm{~A}$ & 150 & 0 \\
\hline 4 & $\mathrm{~B}$ & 0 & 1 \\
\hline 5 & $\mathrm{~B}$ & 50 & 1 \\
\hline 6 & $\mathrm{~B}$ & 100 & 1 \\
\hline 7 & $\mathrm{~B}$ & 150 & 1 \\
\hline 8 & $\mathrm{C}$ & 0 & 2 \\
\hline 9 & $\mathrm{C}$ & 50 & 2 \\
\hline 10 & $\mathrm{C}$ & 100 & 2 \\
\hline 11 & $\mathrm{C}$ & 150 & 2 \\
\hline
\end{tabular}

20 were used for spray at intervals of 60,62 , and 64 days after planting. The control plants were sprayed with $0.1 \%$ Tween 20 solution. Salt treatment was applied 70 days after planting by $0,50,100,150 \mathrm{mM} \mathrm{NaCl}$ for three times every 3 days. The intensity of light above the surface of the plants was 15000 Lux. At the age of 3 months, the leaves were used for extraction of essential oil.

\section{ESSENTIAL OIL ANALYSES}

For identification of essential oil components, dried samples of each treated plant were used. Plant material was hydro-distilled for two hours by Clevenger type apparatus on the basis of the European Pharmacopoeia approach (Anonymous, 1997). The components of the obtained essential oil were determined by GC and GCMS analysis. The GC-Mass apparatus used for the identification of essential oil compounds 
was Agilent 6890; it was equipped with an HP-5MS fused silica column $\left(30 \times 0.25 \mathrm{~mm}^{2}\right)$. Film was $0.25 \mu \mathrm{m}$ thick. The apparatus interfaced with an Agilent 5975 mass selective detector. The temperature of the oven was programmed from 60 to $280{ }^{\circ} \mathrm{C}$ at the rate of $4{ }^{\circ} \mathrm{C} /$ min. The used carrier gas was Helium at a flow rate of $2 \mathrm{ml} / \mathrm{min}$. The voltage of ionization was $70 \mathrm{eV}$, the temperature of injector $280{ }^{\circ} \mathrm{C}$, and the temperature of ion source $200{ }^{\circ} \mathrm{C}$. The oil parts were determined by mass spectra collation of compounds with computer library mass spectra, or with credible components, and proved by comparison of their retention indices (RI) either with valid components retention indices, or with published data in various references (Davies, 1990; Shibamoto, 1987).

\section{RESULTS}

Twenty components were present in the essential oil of control samples, which constituted $99.99 \%$. The major parts were: Geranial (22.52\%), Citral (15.88\%) Germacrene D (7.42\%), Caryophyllene (7.11\%), Benzenamine (6.30\%), Spathulenol (6.00\%) and Curcumene (5.44\%). The components of the essential oil were classified into five main groups: oxygenated monoterpenes, monoterpene hydrocarbons, oxygenated sesquiterpenes, sesquiterpenes hydrocarbons, and other compounds such as fatty acids and hydrocarbons. The highest (58.74\%) and smallest (31.5\%) values of total monoterpene (oxygenated and hydrocarbons) were recorded in treatments No. 2 and 8, respectively. Control plants had the largest amount of total sesquiterpenes (oxygenated and hydrocarbons), while its lowest amount was seen in treatment No. 7.

In total, eleven treatments were carried out in this study. The types as well as the amounts of major oil components varied between treated plants (Table 2). The control samples had the highest amounts of Citral (15.88\%) and Caryophyllene (7.11\%), while their lowest concentrations were in treatments No. 8 (6.06\%) and No. 11 (0\%), respectively. Maximum values of Germacrene D (18.33\%) and Spathule- nol (9.35\%) were found in treatment No. 11, and minimum values of these components were seen, respectively, in treatments Nos. 4, 5, 6, 8, and 9 (0\%) and No. 7 (4.25\%). The largest quantities of Geranial was found in treatment No. 2 (24.89\%); however, treatment No. 8 comprised the smallest amount $(9.38 \%)$ of it. Treatment No. 7 contained the highest percentage $(13.29 \%)$ of $9,12,15$-Octadecatrineoic, although this compound existed in a trace amount in treatment No. 11 and also in control samples.

A significant positive correlation $(r=57$, $p \leq 0.05)$ was observed between Germacrene $\mathrm{D}$ and salt concentrations. Furthermore, Curcumene had a significant negative correlation $(r=-0.67, p \leq 0.05)$ with salt concentration. Paired sample tests showed significant differences $(p \leq 0.05)$ between major components of the essential oil with salt concentrations. It means that variations in salt concentrations lead to significant differences in the amount of parts of the essential oil. This condition holds true for 24-epibrassinolide concentration with major components of the essential oil.

Since in this plant the quality of the essential oil depends on the percentages of two isomers of Citral (Neral and Geranial) and also Limonene, we reviewed the amounts of these components between treatments. The applied treatments on the basis of 24-epibrassinolide concentration were classified into three groups; there was no concentration of 24-epibrassinolide in one group $(\mathrm{A})$, while in the others, (B) and (C), 1 and $2 \mu \mathrm{m}$ of it were used, respectively. In group $\mathrm{A}$, the Limonene amount was decreased in comparison to control plants and the largest amount of Limonene were seen in the plants treated with $150 \mathrm{~m} \mu$ of salt. In group $\mathrm{B}$, the percentage of Limonene increased in concentrations of 0 and $50 \mathrm{~m} \mu$ of salt, but by increasing the concentration of salt its percentages decreased. In comparison to control plants, Limonene amounts were decreased in group C. In this group, the highest value of Limonene was recorded in treated samples with $50 \mathrm{~m} \mu$ of salt and $2 \mathrm{~m} \mu$ of 24 -epibrassinolide. 


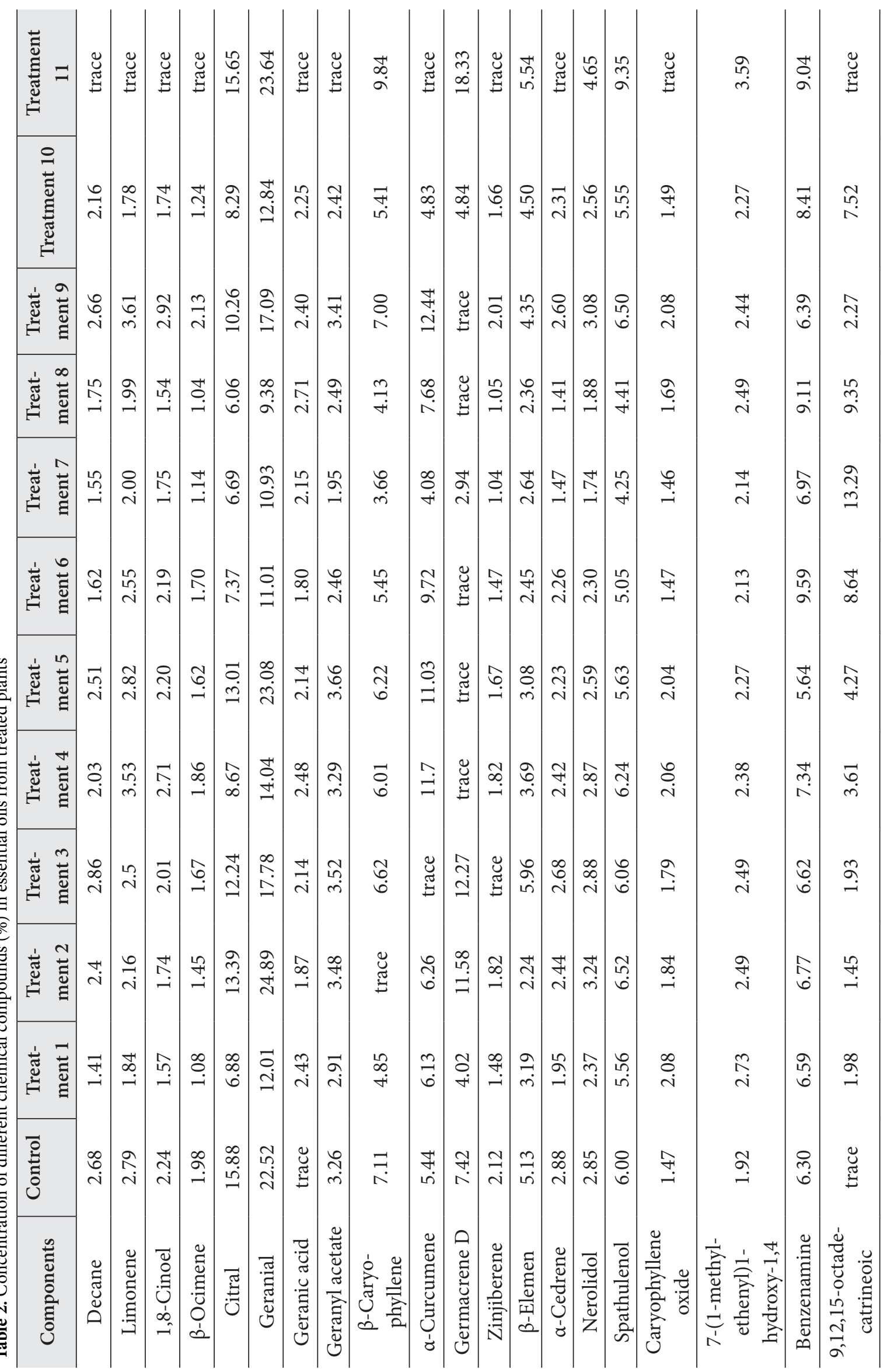


The concentrations of Geranial in group A, with the exception of treatment No. 2 (50 $\mathrm{m} \mu$ of salt and $0 \mathrm{~m} \mu 24$-epibrassinolide), decreased in comparison to control samples. This case was seen in the treatments of group B and the highest percentage of Geranial was found in treatment No. 5, which had $50 \mathrm{~m} \mu$ of salt and $1 \mathrm{~m} \mu$ of 24 -epibrassinolide. In the first three treatments of group $\mathrm{C}$, the amounts of Geranial decreased in comparison to control samples, while in treatment No. 4 its highest value was observed.

\section{DISCUSSION}

In the present study, the composition of essential oil of eleven treated samples of $L$. citriodora were compared with control samples. Essential oils are also known as plant secondary metabolites and consist of a mixture of different components. It has uses in different industries, including the pharmaceutical, tobacco, and food industries (Aflatuni, 2005). Earlier literature sources show that the essential oil of this species is very useful. In addition to medicinal and culinary uses, it has different industrial applications. For example, studies proved that the main parts of the essential oil such as Citral (Jeon et al., 2009), Limonene (Tripathi et al., 2003), Caryophyllene oxide and Neral (Cheng et al., 2009) have an insecticidal effect, although two last components were absent or present in low concentrations in the samples we examined. Although very different components are present in the essential oil of L. citriodora, its quality mainly depends on the presence of the two isomers of Citral - Neral and Geranial, and Limonene. The components of the essential oil depend on different factors such as the origin source, parts of the plant sampled (Gil et al., 2007), the stage of plant development (Argyropoulou et al., 2007) and also physiological stresses (Askari et al., 2016). Rodrigo et al. (2009) stated that for the production of high quality aromatic oils, excellent raw materials are required. For these, appropriate agricultural methods, correct date of collection, suitable industrial processing and storage conditions, and all measures that can affect the sensory state of the ultimate product must be borne in mind. Among the above mentioned agents, the source of origin and physiological stresses are very crucial factors for L. citriodora. Studies have shown that in this species, the composition of essential oil mainly depends on the habitat and the kind of the plant, on the percentage of main components, and on the base of origin source. For example, Hudaib et al. (2013) examined the essential oil of the Jordanian cultivated plant of this species. They found that 1, 8-Cineole (11.7\%), $\gamma$-terpineol (3.4\%), $\beta$-Caryophyllene (2.6\%), a-Curcumene (6.3\%), Spathulenol (4.6\%), and Caryophyllene oxide (3.1\%) were the prominent parts. While in the Moroccan population of it 1, 8-Cineole (12.4\%), Geranial (9.9\%), 6-methyl-5-hepten-2-one (7.4\%) and Neral (6.9\%) were the main components (Bellakhdar et al., 1994). In addition, our findings were in agreement with the above results. The kinds and the percentages of the main components in our control and treated plants varied in comparison to the Moroccan and Jordanian samples.

Our findings showed that physiological stresses have significant effects on the quality of the essential oil in this plant. The highest value of Geranial was recorded in the presence of $100 \mathrm{~m} \mu$ of salt and $0 \mathrm{~m} \mu 24$-epibrassinolide. It means that moderate salt treatment maximized the quality of the essential oil. Furthermore, application of 2 and $1 \mu \mathrm{m}$ of 24-epibrassinolide with 150 and $50 \mathrm{~m} \mu$ of salt had similar effects, but percentages of Geranial in these conditions were lower. Our results confirmed previous studies: for example, recently Shahhoseini et al. (2013) have shown that the maximum amount of Geranial was found in dried samples in $30^{\circ} \mathrm{C}$ oven and an increment of the oven temperature had negative effects. In addition, an increase of soil EC slightly increased its amount.

$6,9,12$-octadecatrienoic acid is a very important fatty acid. This component has biologically prominent functions in the human body. For example, it is a substrate for the synthesis of eicosanoids, having a hand in the cholesterol transport and oxidation. Furthermore, 6, 9,12-octadecatrienoic acid is a component of 
plasma membrane. Studies showed that insufficient dietary intake or bad organization of this acid cause many inflammatory and degenerative conditions. Recent investigations confirmed its health-promoting virtues in the prevention and therapy of some disorders such as cardiovascular diseases, atopic dermatitis, diabetes, cancers as well as rheumatoid arthritis (Białek, Rutkowska, 2015). Although this fatty acid has very low concentration in control samples, its percentage was increased by treatments, so that it reached $13.29 \%$ in treatment No. 7. It seems that increment concentrations of 24-epibrassinolide had a significant effect on the production of this component, but increasing the concentrations of salt prevented it.

Monoterpenes and Sesquiterpenes were two main groups of components. In all of the studied samples, percentages of Monoterpenes were higher than those of Sesquiterpenes. Studies have confirmed that Monoterpenes have different uses. For example, Isman (2006) stated that these components act as fumigants, repellents, or insecticides against insects of stored products.

Our results showed that environmental agents can change Monoterpene amounts in this plant. The highest value of Monoterpenes occurred in presence of $50 \mathrm{~m} \mu$ of salt without any 24-epibrassinolide. It means that mild salt stress stimulated production of Monoterpenes. While the lowest amount of it was reiterated at the highest values of salt and 24-epibrassinolide. Investigations showed that other factors such as drying temperature can affect the Monoterpenes percentages in essential oils. For example, Shahhoseini et al. (2013) suggested that the highest value of total Monoterpenes occurred in plant samples that were dried in the oven cooler than $30^{\circ} \mathrm{C}$.

Our findings confirmed that significant variations occurred in compositions of essential oil in treated plants. Some of these variations are useful for us, because they improve the essential oil. These results are in agreement with previous studies (Rudich et al., 1981; Adams, 1991). They showed that low to moderate salinity levels reached by increasing $\mathrm{NaCl}$ or other nutrients are use to improve the quality of crops.
Received 3 July 2016

Accepted 20 August 2016

\section{References}

1. Ali B, Hasan SA, Hayat S, Hayat Q, Yadav S, Fariduddin Q, Ahmad A. A role for brassinosteroids in the amelioration of aluminium stress through antioxidant system in mung bean (Vigna radiate L. Wilczek). Environ Exper Bot. 2008; 62: 153-59.

2. Aflatuni A. The yield and essential oil content of mint (Mentha ssp.) in northern Ostrobothnia. J Essent Oil Res. 2005; 14: 243-6.

3. Anonymous. European Pharmacopoeia. 3rd ed. France; Strasbourg; 1997.

4. Argyropoulou C, Daferera D, Tarantilis PA, Fasseas C, Polissiou M. Chemical composition of the essential oil from leaves of Lippia citriodora HBK (Verbenaceae) at two developmental stages. Biochem Sys Ecol. 2007: 35 : 831-7.

5. Askary M, Talebi SM, Amini F, Dousti Balout Bangan A. Effect of $\mathrm{NaCl}$ and iron oxide nanoparticles on Mentha piperita essential oil composition. Environmental Experimental Biology. 2016; 14: 27-32.

6. Behnamnia M, Kalantari Kh, Rezanejad F. Exogenous application of brassinosteroids alleviates drought-induced oxidative stress in Lycopersicon esculentum L. Gen. Appl. Plant Physiol. 2009; 35: 22-34.

7. Bellakhdar J, Idrissi AI, Canigueral S, Iglesias J, Vila R. Composition of Lemon Verbena (Aloysia triphylla (L'Herit.) Britton) oil of Moroccan origin. J Essent Oil Res. 1994; 6(5): 523-6.

8. Białek M, Rutkowska J. The importance of $\gamma$-linolenic acid in the prevention and treatment Postępy Higieny i Medycyny Doświadczalne. 2015; 69: 892-904. Polish.

9. Bishop A, Mähönem AP, Helariutta Y. Signs of changes: hormone receptors that regulate plant development. Development. 2006; 133: 1857-69. 
10. Catalan CAN, De Lampasona MEP. The chemistry of the genus Lippia (Verbenaceae). In: Kintzios SE, editor. Oregano: The Genera Origanum and Lippia. London; Taylor and Francis; 2002.

11. Charles DJ, Joly RJ, Simon JE. Effect of osmotic stress on the essential oil content and composition of peppermint. Phytochemistry. 1990; 29: 2837-40.

12. Cheng SS, Liu JY, Huang CG, Hsui Chen WJ, Chang ST. Insecticidal activities of leaf essential oil from Cinnamomum osmophloeum against three mosquito species. Bioresour Technol. 2009; 100: 457-64.

13. Davies NW. Gas chromatographic retention indices of monoterpens of methyl silicons and carbowax $20 \mathrm{~m}$ phases. J Chromatogr. 1990: 503: 1-24.

14. Di Leo Lira P, van Baren CM, Retta D, Bandoni AL, Gil A, Gattuso M, Gattuso S. Characterization of Lemon Verbena (Aloysia citriodo$r a$ Palau) from Argentina by the essential oil. J Essent Oil Res. 2008; 20(4): 350-3.

15. Duarte MCT, Figueira GM, Sartoratto A, Rehder VLG, Delarmelina C. Anti- candida activity of Brazilian medicinal plants. J Ethnopharmacol. 2005; 97: 305-11.

16. Eraslan F, Günes A, Inal A, Çiçek N, Alpaslan M. Comparative physiological and growth responses of tomato and pepper plants to fertilizer induced salinity and salt stress under greenhouse conditions. In: International Meeting on Soil Fertility Land Management and Agroclimatology. 2008 Oct 29-Nov 1; Kusadasi, Turkey.

17. Gil A, Van Baren CM, Lira P, Bandoni AL. Identification of the genotype from the content and composition of the essential oil of lemon verbena (Aloysia citriodora Paláu). J. Agric. Food Chem. 2007; 55: 8664-9.

18. Grattan SR, Grieve CM. Mineral element acquisition and growth response of plants growth in saline environments. Agric Ecosyst Environ. 1992; 38: 275-300.
19. Hayat S, Hasan SA, Yusuf M, Hayat Q, Ah$\operatorname{mad}$ A. Effect of 28-homobrassinolide on photosynthesis, fluorescence and antioxidant system in the presence or absence of salinity and temperature in Vigna radiata. Environ Exper Bot. 2010; 69: 105-12.

20. Hudaib M, Tawaha KH, Bustanji Y. Chemical profile of the volatile oil of Lemon verbena (Aloysia citriodora Paláu) growing in Jordan. Essent Oil Bear Pl. 2013; 16(5); 568-74.

21. Isman MB. Botanical insecticides, deterrents, and repellents in modern agriculture and an increasingly regulated world. Annu Rev Entomol. 2006; 51: 45-66.

22. Jeon JH, Lee $\mathrm{CH}$, Lee HS. Food protective effect of geraniol and its congeners against stored food mites. J Food Prot. 2009; 72(7): 1468-71.

23. Kang JG, Van Iersel MW. Nutrient solution concentration affects shoot: root ratio, leaf area ratio, and growth of subirrigated salvia (Salvia splendens). HortScience. 2004; 39: 49-54.

24. Letchamo W, Ward W, Heard B, Heard D. Essential oil of Valeriana officinalis cultivars and their antimicrobial activity as influenced by harvesting time under commercial organic cultivation. J. Agric. Food Chem. 2004; 52: 3915-9.

25. Maia NB, Bovi OA, Newton MM. Essential oil production and quality of Mentha arvensis grown in nutrient solution. Acta Hortic. 2001; 548: $181-7$.

26. Pascual E, Slowing K, Carretero E, SánchezMata D, Villar A. Lippia: traditional uses, chemistry and pharmacology: a review. J Ethnopharmacol. 2001; 76: 201-14.

27. Nakashita H, Yasuda M, Nitta T, Asami T, Fujikoa S, Arai Y, Sekimata K, Takatsuto S, Yamaguchi I, Yoshida S. Brassinosteroids functions in a broad range of disease resistance in tobacco and rice. Plant J. 2003; 33: 887-98.

28. Ogweno JO, Song XS, Shi K., Hu WH, Mao WH, Zhou YH, Yu JQ, Nogues S. Brassinosteroids alleviate heat induced inhibition of photosynthesis by increasing carboxylation 
efficiency and enhancing antioxidant systems in Lycopersicon esculentum. J. Plant Growth Regul. 2008; 27: 49-57.

29. Infante R, Rubio P, Contador L, Moreno V. Effect of drying process on lemon verbena (Lippia citrodora Kunth) aroma and infusion sensory quality. Int J Food Sci Technol. 2009; 45: 75-80.

30. Rudich J, Rendon E, Stevens MA, Ambri A. Use of leaf water potential to determine water stress in field grown tomato plants. J Am Soc Hortic Sci. 1981; 106: 732-6.

31. Santos-Gomes PC, Fernandes-Ferreira M, Vicente AMS. Composition of the volatile oils from flowers and leaves of Vervain (Aloysia triphylla (L'Herit.) Britton) grown in Portugal. J Essent Oil Res. 2005; 17: 73-8.

32. Sartoratto A, Machado ALM, Delarmelina C, Figueira GM, Duarte MCT, Rehder VLG. Composition and antimicrobial activity of essential oils from aromatic plants used in Brazil. Braz J Microbiol. 2004; 35: 275-80.

33. Sasse JM. Physiological actions of brassinosteroids: an update. Plant Growth Regul. 2003; 22: $276-88$.

34. Sellami IH, Wannes WA, Bettaieb I, Berrima S, Chahed T, Marzouk B, Limam F. Qualitative and quantitative changes in the essential oil of Laurus nobilis L. leaves as affected by different drying methods. Food Chem. 2011; 126: 691-7.

35. Shahhoseini R, Estaji A, Hosseini N, Ghorbanpour M, Omidbaigi R. The effect of different drying methods on the content and chemical composition of essential oil of Lemon verbena (Lippia citriodora). Essent Oil Bear Pl. 2013; 16(4): 474-81.

36. Shibamoto T. Retention indices in essential oil analysis. In: Sandra P, Bicchi C., editors. Capillary Gas Chromatography in Essential Oil. Springer Verlag; 1987.

37. Stutte GW. Process and product: recirculation hydroponics and bioactive compounds in a controlled environment. HortScience. 2006; 41: 526-30.
38. Terblanche FC, Kornelius G. Essential oil constituents of the genus Lippia (Verbenaceae)a literature review. J Essent Oil Res. 1996: 8: 471-85.

39. Tripathi AK, Prajapati V, Khanuja SP, Kumar S. Effect of d-limonene on three storedproduct beetles. J Econ Entomol. 2003; 96(3): 990-5.

40. Valentão P, Andrade PB, Areias F, Ferreres F, Seabra RM. Analysis of vervain flavonoids by HPLC /Diode array detector method. Its application to quality control. J Agric Food Chem. 1999; 47: 4579-82.

\section{Fariba Amini, Gholam Reza Asghari, Seyed Mehdi Talebi, Mehry Askary, Marziyeh Shahbazi}

\section{APLINKOS VEIKSNIŲ POVEIKIS LIPPIA CITRIODORA ETERINIO ALIEJAUS JUNGINIAMS}

\section{Santrauka}

Lippia citriodora Pietų Amerikoje yra endeminè rūšis, o pasaulyje ji buvo auginama dèl i citriną panašaus lapų aromato. Šiame straipsnyje pateikiami skirtingų $\mathrm{NaCl}$ ir 24-epibrasinolido koncentracijų poveikio eterinio aliejaus junginiams tyrimų rezultatai. Tyrimo metu naudota vienuolika skirtinguc $\mathrm{NaCl}$ ir epibrasinolido koncentracijų. Kontrolinių augalų eterinio aliejaus sudètyje yra 20 junginių, kurių didžiąją dalị sudarė geranialis $(22,52 \%)$, citralis $(15,88 \%)$, germakrenas D $(7,42 \%)$, kariofilenas $(7,11 \%)$, benzenaminas $(6,30 \%)$, spatulenolis $(6,00 \%)$ ir kurkumenas (5,44\%). Reikšmingos teigiamos / neigiamos koreliacijos pastebètos tarp kai kurių eterinių aliejų komponentų su druskos koncentracijomis. Gauti rezultatai rodo, kad fiziologinis stresas turi reikšmingą poveikį Lippia citriodora augalo eterinio aliejaus kokybei.

Raktažodžiai: epibrasinolidas, eterinis aliejus, Lippia citriodora, stresas, druska 